\title{
Decomposition Behavior of Biodegradable and Single-Use Tableware Items in the Warnow Estuary (Baltic Sea)
}

\author{
Amina Baccar Chaabane ${ }^{1,2, *}$, Esther Robbe ${ }^{1,3} \mathbb{D}^{-}$, Gerald Schernewski ${ }^{1,3}\left(\mathbb{D}\right.$ and Hendrik Schubert ${ }^{2}$ \\ 1 Leibniz-Institute for Baltic Sea Research, 18119 Rostock, Germany; esther.robbe@io-warnemuende.de (E.R.); \\ gerald.schernewski@io-warnemuende.de (G.S.) \\ 2 Aquatic Ecology, University of Rostock, 18055 Rostock, Germany; hendrik.schubert@uni-rostock.de \\ 3 Marine Research Institute, Klaipeda University, 92294 Klaipeda, Lithuania \\ * Correspondence: baccaramina@gmail.com; Tel.: +49-15234529755
}

Citation: Baccar Chaabane, A.; Robbe, E.; Schernewski, G.; Schubert, H. Decomposition Behavior of Biodegradable and Single-Use Tableware Items in the Warnow Estuary (Baltic Sea). Sustainability 2022, 14, 2544. https://doi.org/ $10.3390 /$ su14052544

Academic Editor: Xiaying Xin

Received: 15 January 2022

Accepted: 21 February 2022

Published: 22 February 2022

Publisher's Note: MDPI stays neutral with regard to jurisdictional claims in published maps and institutional affiliations.

Copyright: (C) 2022 by the authors. Licensee MDPI, Basel, Switzerland. This article is an open access article distributed under the terms and conditions of the Creative Commons Attribution (CC BY) license (https:// creativecommons.org/licenses/by/ $4.0 /)$.

\begin{abstract}
Due to the increasing demand for alternative and supposedly more sustainable single-use tableware compared to conventional fossil-based plastic items, there now exists a broad variety of innovative new bio-based and biodegradable items. The aim of this research is to conduct a monitoring of the biodegradability of selected tableware items: polylactic acid (PLA), crystallized polylactic acid (CPLA), wood, palm leaf, paper/cellulose and sugar cane bagasse, as well as a common fossil-based plastic polystyrene (PS) as a comparative material in a water column, to determine their possible use as a substitute for single-use plastic flatware. In situ experiments were performed over a one-year period to consider changes in water temperature, salinity gradients, $\mathrm{pH}$ values and dissolved oxygen (DO). The main findings show that tableware items composed of palm leaf, sugar cane bagasse and paper are less resistant to estuary conditions. However, wood, PLA, CPLA and PS items showed a certain resistance during the experimentation period. Furthermore, items placed in the upper incubators degraded relatively faster than those of the same material but placed in the lower incubators. The results indicate that temperature and exposure to natural light could be an important factor in terms of accelerating the degradation of the materials considered.
\end{abstract}

Keywords: biodegradability; bio-based tableware; conventional plastic; degradation rate; marine litter; Warnow River estuary

\section{Introduction}

Marine litter is recognized worldwide as a rising pollution problem affecting all the oceans and coastal areas of the world [1-3]. The increasing production and use of durable synthetic materials such as plastics has led to a gradual but significant accumulation of litter in the marine environment, making it ever more difficult to tackle $[4,5]$.

Several studies have shown that marine litter exists in most oceans and seas, and their source and pathways have become an important focus of research [6]. This same work indicates that the identification of the origin of litter can help tackle the problem by implementing strategies to stop and avoid any pollutant reaching the water. Marine litter originates mainly from public littering, poor waste management practices, industrial activities, sewage-related debris and storm water discharge, all of which can be transported via rivers [7-9], until it reaches the seas and the oceans.

According to the Helsinki Commission (HELCOM), marine litter is a clearly visible problem along the Baltic Sea coastline. Around $70 \%$ of the marine litter in the Baltic Sea is plastic and represents a special concern due to its slow rate of degradation and its risk to the environment $[10,11]$. Therefore, a regional goal has been agreed within the area dealt by the Baltic Marine Environment Protection Commission on significantly reducing the amount of marine litter by 2025 and preventing harm from litter in the coastal and marine environment [12]. 
In fact, plastic pollution in particular is globally distributed across all oceans due to its properties of buoyancy and durability, and the sorption of toxicants to plastic while traveling through the environment $[10,11]$.

In the Warnow estuary of Rostock, research carried out on existing plastics in the sediments showed that most the abundant items were plastic fragments $(32.6 \%)$, followed by flat pieces of plastic (strapping bands, $20 \%$ ), cups and cup lids $(6.3 \%)$, corrugated plastic $(5.9 \%)$, food containers incl. fast food containers (5.6\%), etc. In fact, $26 \%$ of the litter is generated by residents and tourists [13].

In addition, according to the European Union, $80 \%$ to $85 \%$ of marine litter is plastic and single-use plastic (representing $50 \%$ of the total) which results from a diverse range of commonly used fast-moving consumer products that are discarded after having been used once for the purpose for which they were provided. These are rarely recycled and are prone to becoming litter [14]. Furthermore, most plastics do not fully degrade, but split into tiny fragments [15]. For example, Rochman et al. [16] revealed that synthetic polymers in the ocean should be considered as hazardous waste. Some studies report little or no physical or chemical harm to marine biota [17], while others, which include the use of a thermodynamic approach and the simulation of physiological conditions in the gut, suggest that chemicals in plastics might be released to organisms after ingestion $[18,19]$.

Despite the advantages of using plastics, their harmful effects on nature remain a problem to be solved. Hence, several research studies have been aimed at the development of alternative materials to single-use plastic items. Research and development are on-going to create harmonized standards for these items to be classified as biodegradable in water, which is needed before relevant products can be introduced to the market [20].

In fact, several products have been developed as environmentally friendly that can substitute the use of non-degradable materials, particularly in the water. For example, biodegradable items are defined as any material likely to be degraded under appropriate conditions of temperature, humidity, oxygenation and $\mathrm{pH}$, and under the effect of microorganisms, fungi or bacteria [21]. The outputs of biodegradability are the formation of water, $\mathrm{CO}_{2}$ and/or methane and possibly by-products (residues, new biomass) that are not toxic to the environment [22]. Moreover, eco-friendly plastics, namely bio-based plastics, can be produced from renewable resources, and biodegradable plastics degrade in the environment to solve global environmental and waste management problems [23]. With society's growing concern for sustainable consumption, production and waste management, biodegradable packaging may appear as an environmentally friendly option and could rapidly become an attractive commercial feature [24]. In addition, the escalating problems caused by non-degradable plastics have led to the development of biodegradable plastics [25]. These polymers have the property of being biodegradable and are named biodegradable polymers (BDPs) or biodegradable plastics, which refers to polymeric materials that are capable of undergoing decomposition into carbon dioxide, methane, water, inorganic compounds or biomass in which the predominant mechanism is the enzymatic action of microorganisms [26].

Nowadays, the term 'biodegradable' is still under discussion between experts and decision makers. It is a term that should be distinguished from similar terms (biodegradation, degradability, etc.) and used to describe a material with some care. Biodegradability was first defined in terms of use in the soil; however, further studies have proved its use in water columns.

According to the United Nation's (UN) environment program, polymers, which biodegrade under favorable conditions on land, are much slower to break up in the ocean, and their widespread adoption is likely to contribute to marine litter and consequent undesirable consequences for marine ecosystems [27].

These experiences could lead to different hypotheses based on the origin of the materials, their behavior in the natural environment and to the affecting environmental changes. Regarding the PLA and CPLA as well as plastic items (in this case PS), their biodegradability in water columns does not seem to be achievable in one year. Other products (palm 
leaves, sugar canes, wood and paper) could be degradable after a shorter period, for the reason that this is linked to their original state and their behavior in nature.

The objective of the current research is to test the biodegradability of plastic tablewarereplacement items, PLA, CPLA, palm leaf, sugar cane (bleached/unbleached), wood, paper and PS, in a natural estuarine environment in Rostock city. To do this, the biodegradability of selected items was monitored via in situ experiments over a one-year period while monitoring the physicochemical parameters of the water (temperature, salinity, DO and $\mathrm{pH}$ ) and the natural habitat of marine organisms on the incubators (barnacles, mussel, algae, etc.). The motivation behind this research is to understand the resistance of the selected items to the marine and natural conditions, and to reinforce international research into finding biodegradable alternatives to single-use plastic.

\section{Study Site and Methods}

\subsection{Methods}

The methodology of work began by setting the items to be tested. Used samples are already commercialized and used at some coastal events in Rostock (festivals, markets, street-food events, Hanse Sail, etc.). Once the items were provided by the municipality, a documentation with the description and the characteristics of each sample were noted.

To ensure a secure enrolment of the experiments in the water column, it was essential to develop a specific and rigid tool that ensures the natural circulation of the water and the contact with the product. Therefore, adapted incubators were designed and constructed within the workshop of the Leibniz Institute for Baltic Sea Research, described in Section 2.3. In addition, choosing the areas had to be very precise by respecting some criteria such as water depth, salinity, access to the station, water clarity and surrounding activities. Finally, incubators were prepared to be placed according to the research protocol.

Installed incubators were controlled periodically to clean them and to ensure an adequate running of the experiments. Additionally, the items' degradation rate (DR) was monitored in parallel with the water's physicochemical parameters. The work was complemented by data analyses to arrive at possible conclusions and to allow us to make appropriate recommendations.

The concept approach of this study is summarized in Figure 1.

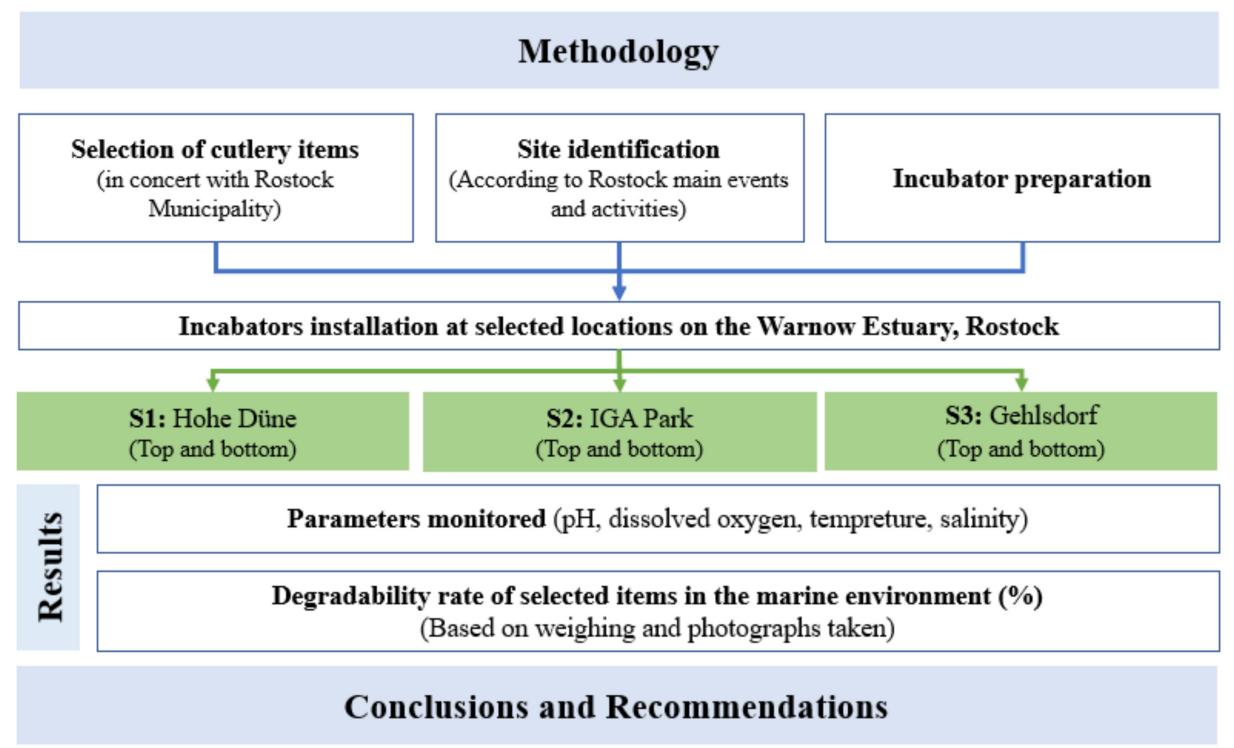

Figure 1. The concept approach.

\subsection{Study Site}

The incubation of different samples took place in the Warnow River estuary crossing Rostock city, which is located in the German Federal state of Mecklenburg-Western 
Pomerania on the Baltic German coast. The Warnow River, which is $155 \mathrm{~km}$ long, is the second longest river in Mecklenburg-Western Pomerania. Through this channel salty ocean water reaches the estuary and spreads over the whole river. The salt gradient between the Baltic Sea and fresh water from the Warnow River drives an estuarine circulation with an inflow (upstream) of saline water near the surface, and an outflow (seaward) of near-surface water [28].

From both sides, the coastal area of the Warnow estuary can be divided according to the different activities such as ship building industry, waste industry, the Rostock port, tourism and recreation, beaches, green areas, reed belts, military area and others. This variety of the sections affects the Warnow directly or indirectly, a reason to do more research and studies about this small and semi-closed area to preserve it and avoid all types of pollution.

The Figure 2 shows the exact location of each chosen station as well as the incubators emplacement.

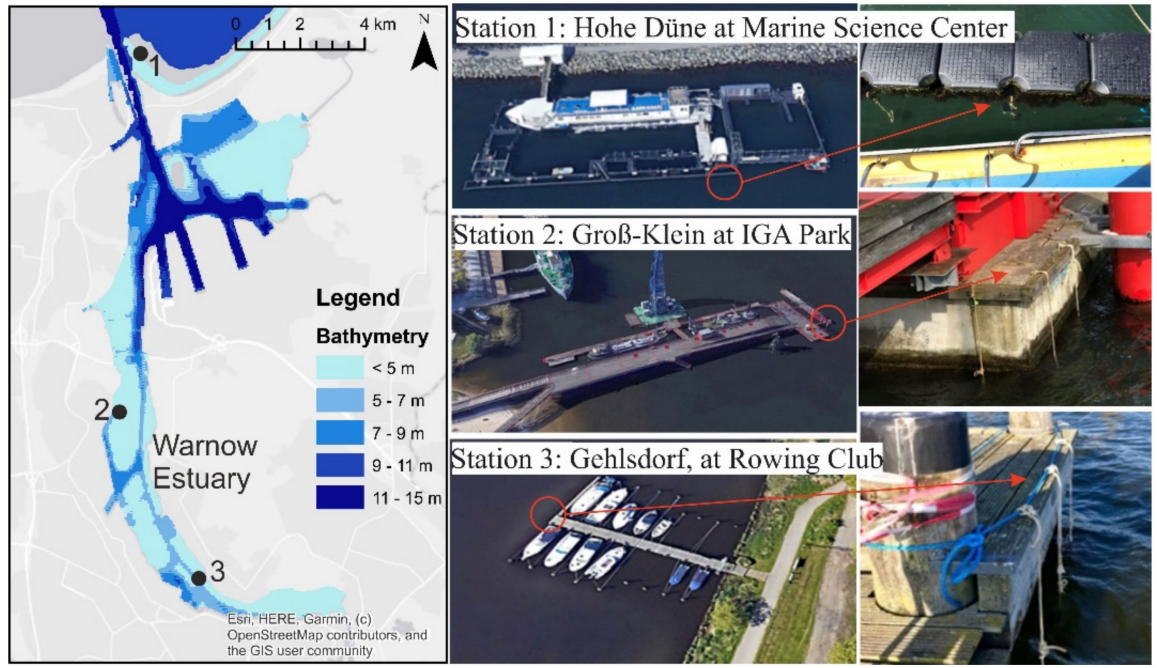

Figure 2. Location of selected stations S1, S2 to S3 in the Warnow River estuary at Rostock city in addition to the hanging incubators in the water column.

The land-side coastal zone area is the most heavily built-on and used urban environment in the world. From both sides, the coastal area of the estuary can be divided according to different industrial activities such as ship building, waste treatment, Rostock port, tourism and recreation, beaches, green areas, reed belts, military area and others. This variety of activities affects the Warnow River directly and indirectly, hence a reason for undertaking more research and studies with regard to this small and semi-enclosed area in order to preserve it and to avoid all types of pollution.

Three different stations were chosen for the location of the incubators and were named in terms of the area in which they were located. They are distributed, respectively from North to South along the Warnow River estuary, as follows: Hohe Düne, IGA Park and Gehlsdorf.

S1. Hohe Düne: This station is at the Marine Science Center which is a seal research center which is part of the Institute for Biosciences at the University of Rostock. It is located at the Marina of Hohe Düne right on the Warnow's east breakwater. The incubators are hung on plastic floating buoys which surround the seal and penguin cages. The geographical coordinates are $54^{\circ} 11^{\prime} 02.4^{\prime \prime} \mathrm{N}, 12^{\circ} 05^{\prime} 43.4^{\prime \prime} \mathrm{E}$. The characteristics of this station are the water depth (around $5 \mathrm{~m}$ ), the water clarity (transparency of the water is high all year round), mechanical effect due to the transport flow involving small boats and yachts (which could be a source of invasive species) and different weather conditions. During the verification of the incubators, the presence of several species, such as small shrimps, medusa, etc., was evident. This station is known by scientific research activities related to different animals such as seals and penguins, it is also an open spot for visitors. 
S2. IGA Park: This station is located at the IGA Park as indicated by its name. This park is located at Schmarl Dorf, known for different activities, such as open-air concerts and musical events, food exposures and even a place of attraction for swimmers and water activities performed throughout the year, etc. On the coastal part of the park, which is exposed to the Warnow River estuary, there is a platform next to the Maritime Museum which extends into the estuary for approximately $165 \mathrm{~m}$. The incubators are hung at the extremity of this platform with the geographic coordinates: $54^{\circ} 08^{\prime} 27.4^{\prime \prime} \mathrm{N}, 12^{\circ} 05^{\prime} 21.2^{\prime \prime} \mathrm{E}$. It is characterized by its exposure to the different currents of the Warnow River and to the sun; parameters that are important and play a role in the degradation of the materials to be tested. The water depth is around $4 \mathrm{~m}$, and water clarity is not high and depends on the season. This station is also characterized by an important growth of mussels. Access is supported by the park administration.

S3. Gehlsdorf: This station is located at the rowing club opposite Rostock city. The boat dock used belongs to the rowing club, and the incubators were hung to the outer end. The geographic coordinates are $54^{\circ} 05^{\prime} 47.8^{\prime \prime} \mathrm{N}, 12^{\circ} 07^{\prime} 54.1^{\prime \prime} \mathrm{E}$. The water depth is approximately $3 \mathrm{~m}$, and the water transparency is very low. This area is known for an intense activity in terms of rowers training throughout the year, and recreational boats being active during the summer season.

The choice of the three stations was based on different relevant criteria that may influence the rapidity of the degradation or the general progress of the experiments. In addition, the accessibility to the station and the security of the incubators during the experimentation period represents a crucial factor that future projects should consider.

\subsection{Incubators Preparation}

Incubators were designed and constructed within the IOW Institute [29]. They are made of a circular hard plastic cage (black part) and a $2 \mathrm{~mm}$ mesh size plastic net which was used to build the walls of each incubator. The mesh size allows good water circulation, which is considered an important mechanical parameter. The steps to get a finalized incubator are presented in the following Figure 3.
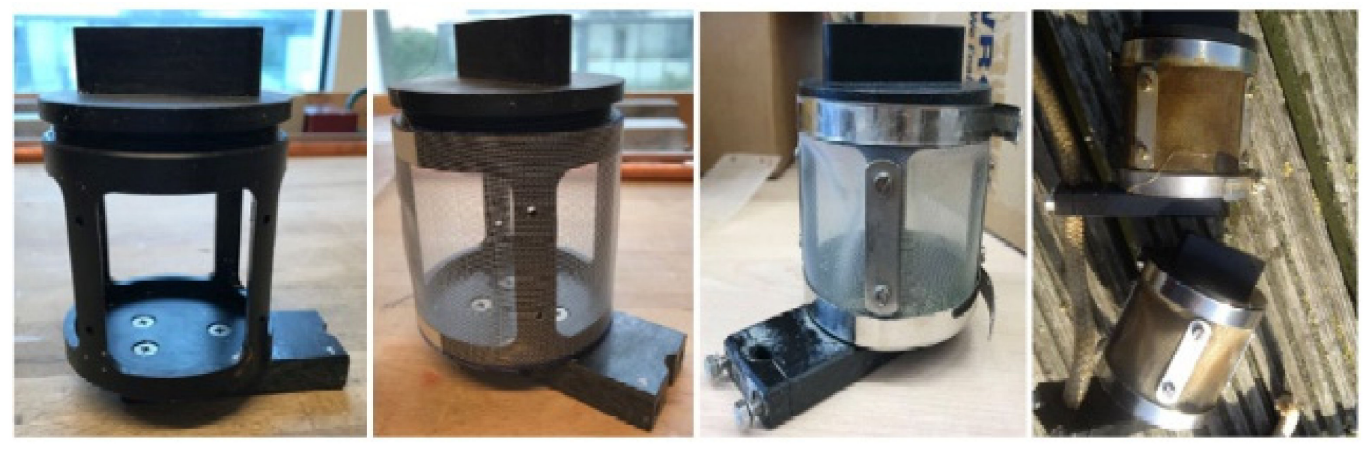

Figure 3. Incubator preparation for experiments.

Tableware items were cut into small pieces in order to fit into the incubators and were weighed and measured. For each item, a sample was placed in an upper incubator (close to the surface, more exposed to sunlight and to pelagic organisms) and in a lower one (closer to the bottom, less exposed to sunlight and to demersal organisms). In total and at each station, 12 incubators were placed in the water in 3 groups of 4 incubators and were attached to ropes. They were hung from the top and fixed with chains to the bottom as shown in Figure 4.

Regarding the label attributed to each incubator, and as an example, at station S1, paper samples were divided into two fragments, one is in the upper incubator (U), hence named M.1.1.U, and the other in the lower one (D) and named M.1.3.D. 

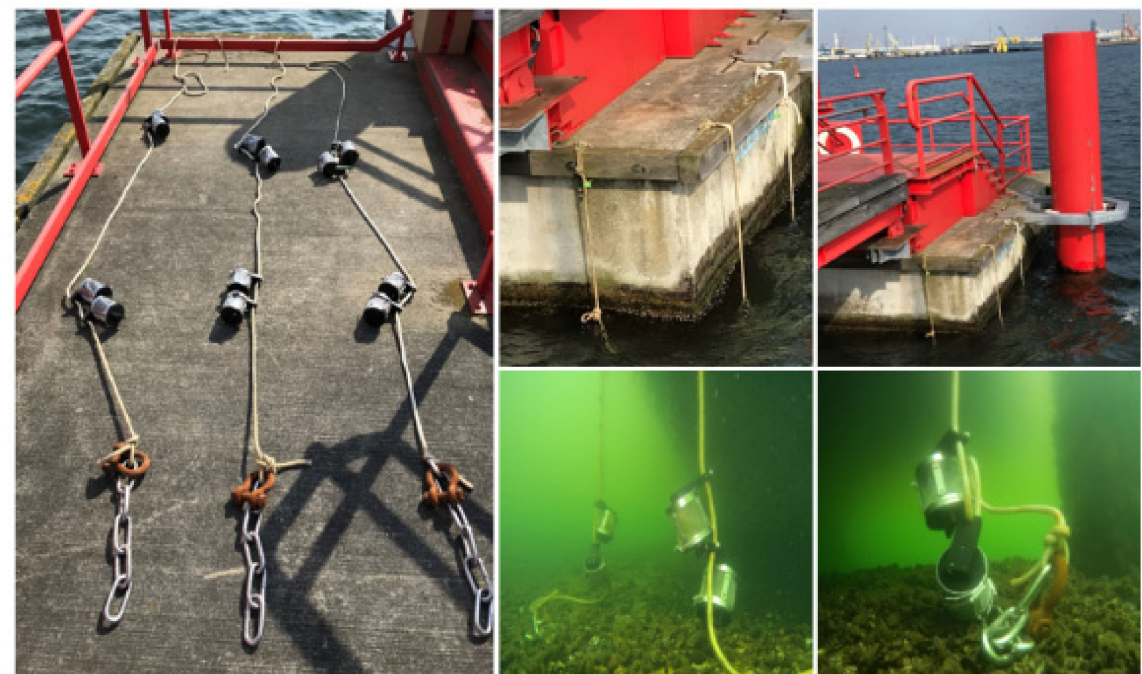

Figure 4. Example of preparation and installation of the attached incubators to ropes.

\subsection{Incubators Installation}

The incubators were installed at a precise spot at each station in order to ensure easy access for parameter monitoring and incubator opening. The ropes were attached at each station into different boarders: at $\mathrm{S} 1$ they were attached to floating buoys, at $\mathrm{S} 2$ to a wooden barrier and at S3 to a rope fixed at the end of the dock. The experiments started at the same period (end of April for S2 and S3 and beginning of May for S1). The idea is to have the same weather conditions simultaneously for the different experiment locations.

At IGA Park, the incubators were hung against a wall (Figure 3), but in the two other stations they were suspended freely in the water column.

\subsection{Used Tableware Items}

Provided tableware items are from a range of different sizes, shapes, colors and densities. They were made of PLA, CPLA, palm leaf, sugar cane bagasse (bleached/unbleached), wood, paper/cellulose and single-used fossil-based conventional plastics (PS). Some examples of used tableware items are presented in Figure 5.
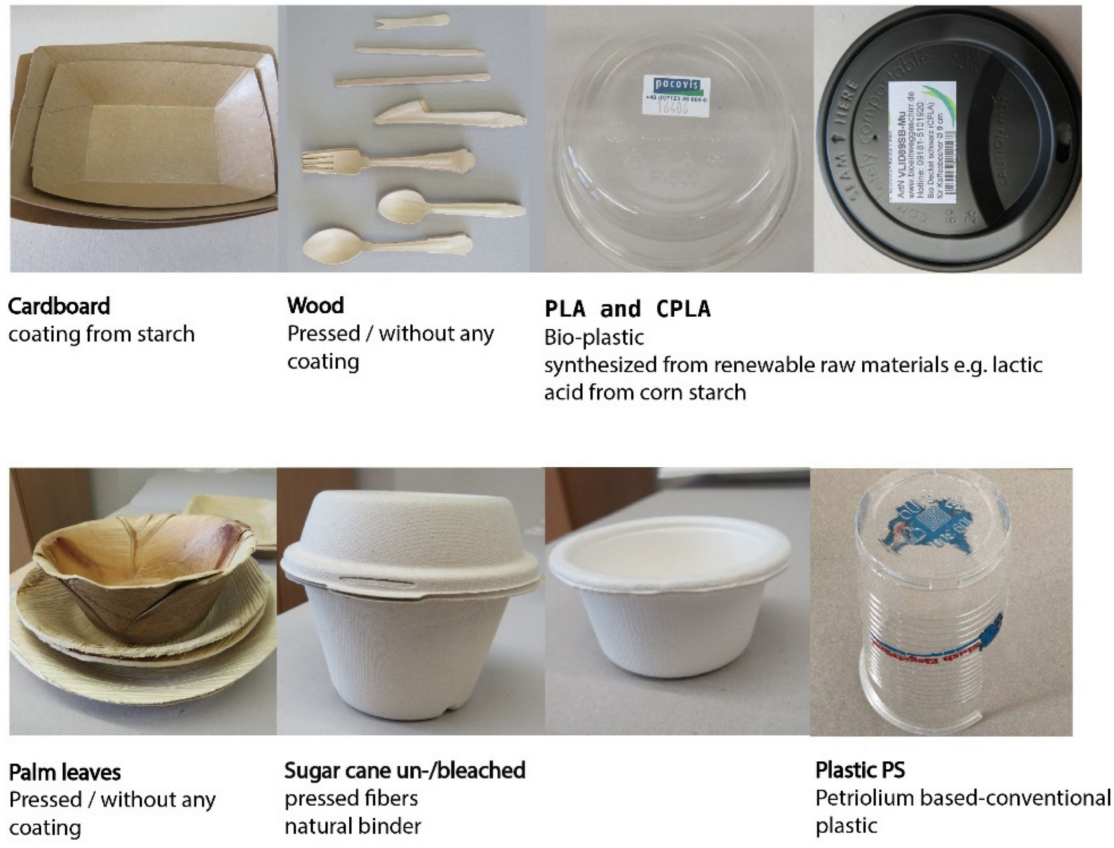

Figure 5. Tableware used for experiments. 
PLA or polylactic acid is a biodegradable polyester which is very versatile and is derived from $100 \%$ renewable resources [30]. It is produced from corn, starch and sugars [31,32]. It has a density value between $1200-1450 \mathrm{~kg} / \mathrm{m}^{3}$, and it is used for packaging food products given its high permeability to water [33]. According to [34], soil burial tests show that the degradation of PLA is slow, and that it takes a long time for degradation to start. For instance, no degradation was observed on the material sheets after 6 weeks in soil.

CPLA or crystallized poly lactic acid is obtained through sugars and corn starches. When producing PLA, lime is added. The material then becomes crystallized and resistant to heat. CPLA, when used for tableware, is considered to be a bioplastic. In a natural environment (soil), it starts to degrade in 5 to 6 months, with complete decomposition after 12 months. If composted with food garbage, it begins to decompose after 2 weeks [35].

According to the technical file relating to the product used:

- $\quad$ The plates and bowls were made from discarded and pressed palm leaf from the "Adaka" nut palm. Depending on the source of the palm leaf used, its density is between $0.7-1.55 \mathrm{~g} / \mathrm{cm}^{3}$ [36].

- The sugar cane bagasse products used in these experiments are obtained from extracting sugar from the cane's marrow leaf "bio-mass" (fiber), which is usually burned. The density of sugar cane is $1.20 \mathrm{~g} / \mathrm{m}^{3}$ [37].

Paper is composed of lignocellulose. The density of paper is $700 \mathrm{~kg} / \mathrm{m}^{3}$ according to $[38,39]$. According to the technical file of the product used, cardboard cups are made from pure cellulose. In order to make the cups resistant to moisture, the cardboard is coated on the inside with a starch film.

Wood packaging is mainly used for the transport of goods and is mainly made of cellulose [24]. The wooden tableware used was made or punched from birch wood, having a density of $623 \mathrm{~kg} / \mathrm{m}^{3}$ [40], using a pressing process. There is no further coating or surface treatment.

Polystyrene (PS) is a synthetic hydrophobic polymer with a high molecular weight and a density of $1060 \mathrm{~kg} / \mathrm{m}^{3}$ [41]. It is recyclable but not biodegradable, and at room temperature, it exists in a solid state. PS, being a transparent hard plastic, is commonly used as disposable tableware [42].

The values of densities give a better understanding of biodegradable items' behavior in water. Some tend to sink while others float. This affects their fragmentation and the behavior of living organisms (which could use the products as habitats or nutrition elements) throughout the experimental period. PLA and sugar cane tend to sink after a certain time, while wood, paper and PS items tend to float. In the case of palm leaf materials, differences in density margins mean that they can either float or sink.

\subsection{Parameter Monitoring Tools}

In order to obtain the required data regarding the measurements of DO, temperature, $\mathrm{pH}$ and salinity, specific tools were used involving cables and measuring device from the Hach HQD digital multimeter which combines reliability, flexibility and ease of use. The devices used for measurement in the water were an HQ40D Portable $\mathrm{pH}$, Conductivity/TDS \& Dissolved Oxygen Meter, Premium Field Kit for Environmental Monitoring with a $5 \mathrm{~m}$ Cable and a CTD48M gear. The follow up of these parameters was done according to a schedule. Initially measurements were done with a frequency of two to three times per month, while at the end of the experimental period, it was done about one to two times per month, depending on the availability of the equipment and access to the stations.

\section{Results}

\subsection{Degradation Rate Monitoring}

The incubators were removed periodically from the water column to clean them and to identify the status of the materials from Hohe Düne after 50 days, 202 days and 339 days after the first day of installation, from IGA Park after 65 days, 165 days and 399 days, and from Gehlsdorf after 64 days, 148 days and 356 days. At the end of the exper- 
imental period, the walls of the incubators were removed, opened at the IOW laboratory, and the results were documented. Samples were weighed and left in labelled bags. The following Tables 1-3 show the difference between the initial and the final weight of the samples after the experimentation period. The degradation rate was calculated using the following formula:

$$
\text { Degradation Rate }:(D R)=(W o-W t / W o) \times 100
$$

where $W_{0}$ and $W_{t}$ are the weights of the initial and degraded items, respectively.

Table 1. Results of the degradation of selected items in Station S1, Hohe Düne (HD).

\begin{tabular}{|c|c|c|c|c|}
\hline Incubators and Content & Initial Weights of Samples & Final Total Weight & $\begin{array}{l}\text { Degradation Rate } \\
\text { (DR) (\%) }\end{array}$ & Final Status of the Item \\
\hline HD.1.1.U Paper & Plate $(1.6 \mathrm{~g})$, small cup $(0.3 \mathrm{~g})$ & $1.1 \mathrm{~g}(-0.8 \mathrm{~g})$ & $42.1 \%$ & Soft to the touch \\
\hline HD.1.2.U Plastics & Cup $(1 \mathrm{~g})$, box $(2.1 \mathrm{~g})$ & $4.3 \mathrm{~g}(+1.2 \mathrm{~g})$ & $0 \%$ & Not degraded \\
\hline HD.1.3.D Paper & Plate $(1.8 \mathrm{~g})$, small cup $(0.4 \mathrm{~g})$ & $1.5 \mathrm{~g}(-0.7 \mathrm{~g})$ & $31.8 \%$ & Soft to the touch \\
\hline HD.1.4.D Plastics & Cup $(1 \mathrm{~g})$, box $(1.8 \mathrm{~g})$ & $3.5 \mathrm{~g}(+0.7 \mathrm{~g})$ & $0 \%$ & Not degraded \\
\hline HD.2.1.U Wood & Spoon $(2.5 \mathrm{~g})$, fork (2 g) & $4.8 \mathrm{~g}(+0.3 \mathrm{~g})$ & $0 \%$ & Soft to the touch \\
\hline HD.2.2.U Palm leaf & Plate $(3.3 \mathrm{~g})$ & $0.6 \mathrm{~g}(-2.7 \mathrm{~g})$ & $81.8 \%$ & Small fibers \\
\hline HD.2.3.D Wood & Spoon (1.6 g), fork (2 g) & $5.8 \mathrm{~g}(+2.2 \mathrm{~g})$ & $0 \%$ & Soft \\
\hline HD.2.4.D Palm leaf & Plate $(2.9 \mathrm{~g})$ & $0 \mathrm{~g}(-2.9 \mathrm{~g})$ & $100 \%$ & Totally degraded \\
\hline HD.3.1.U PLA/CPLA & $\begin{array}{c}\text { PLA (lid } 0.9 \mathrm{~g} \text {, cup } 1.2 \mathrm{~g} \text { )/ } \\
\text { CPLA (lid } 1.9 \mathrm{~g} \text {, spoon } 2.4 \mathrm{~g} \text { ) }\end{array}$ & $6.6 \mathrm{~g}(+0.2 \mathrm{~g})$ & $0 \%$ & Not degraded \\
\hline HD.3.2.U Sugar cane & $\begin{array}{c}\text { Bleached }(1.1 \mathrm{~g}) / \\
\text { unbleached }(1.2 \mathrm{~g})\end{array}$ & $0 \mathrm{~g}(-2.3 \mathrm{~g})$ & $100 \%$ & Totally degraded \\
\hline HD.3.3.D PLA/CPLA & $\begin{array}{c}\text { PLA (lid } 1 \mathrm{~g} \text {, cup } 1.1 \mathrm{~g} \text { )/ } \\
\text { CPLA (lid } 1.7 \mathrm{~g} \text {, spoon } 2 \mathrm{~g} \text { ) }\end{array}$ & $6 \mathrm{~g}(+0.2 \mathrm{~g})$ & $0 \%$ & Not degraded \\
\hline HD.3.4.D Sugar cane & $\begin{array}{c}\text { Bleached }(1 \mathrm{~g}) / \\
\text { unbleached }(1.3 \mathrm{~g})\end{array}$ & $0 \mathrm{~g}(-2.3 \mathrm{~g})$ & $100 \%$ & Totally degraded \\
\hline
\end{tabular}

Table 2. Results of the degradation of selected items in Station S2, IGA Park (I).

\begin{tabular}{|c|c|c|c|c|}
\hline Incubators and Content & Initial Weights of Samples & Final Total Weight & $\begin{array}{c}\text { Degradation } \\
\text { Rate }(\%)\end{array}$ & Final Status of the Item \\
\hline I.1.1.U Plastics/CPLA & $\begin{array}{l}\text { Cup }(0.6 \mathrm{~g}), \text { box }(1.5 \mathrm{~g}) \\
\text { knife }(1.6 \mathrm{~g})\end{array}$ & $4 \mathrm{~g}(+0.3 \mathrm{~g})$ & $0 \%$ & Not degraded \\
\hline I.1.2.U Sugar cane & $\begin{array}{c}\text { Bleached }(2.8 \mathrm{~g}) / \\
\text { unbleached }(1.3 \mathrm{~g})\end{array}$ & $0 \mathrm{~g}(-4.1 \mathrm{~g})$ & $100 \%$ & Totally degraded \\
\hline I.1.3.D Plastics/CPLA & $\begin{array}{l}\text { Cup }(0.6 \mathrm{~g}), \text { box }(1.5 \mathrm{~g}) \\
\text { knife }(1.8 \mathrm{~g})\end{array}$ & $4.5 \mathrm{~g}(+0.6 \mathrm{~g})$ & $0 \%$ & Not degraded \\
\hline I.1.4.D Sugar cane & $\begin{array}{c}\text { Bleached }(2.8 \mathrm{~g}) / \\
\text { unbleached }(1.3 \mathrm{~g})\end{array}$ & $1.4 \mathrm{~g}(-2.7 \mathrm{~g})$ & $65.8 \%$ & Soft to the touch \\
\hline I.2.1.U Wood & Tableware $(1.3 \mathrm{~g}) /(2.2 \mathrm{~g})$ & $7.1 \mathrm{~g}(+3.6 \mathrm{~g})$ & $0 \%$ & Soft to the touch \\
\hline I.2.2.U Palm leaf & Rectangular plate (1.5 g) & $0 \mathrm{~g}(-1.5 \mathrm{~g})$ & $100 \%$ & Totally degraded \\
\hline I.2.3.D Wood & Tableware $(1.8 \mathrm{~g}) /(1.7 \mathrm{~g})$ & $6.8 \mathrm{~g}(+3.3 \mathrm{~g})$ & $0 \%$ & Soft to the touch \\
\hline I.2.4.D Palm leaf & Plate $(1.6 \mathrm{~g})$ & $1.1 \mathrm{~g}(-0.5 \mathrm{~g})$ & $31.2 \%$ & Small fibers \\
\hline I.3.1.U Paper & Plate (1.7 g), cup (2 g) & $0 \mathrm{~g}(-3.7 \mathrm{~g})$ & $100 \%$ & Totally degraded \\
\hline I.3.2.U PLA/CPLA & $\begin{array}{c}\text { PLA (cup } 2.5 \mathrm{~g}) / \\
\text { CPLA (knife } 2.3 \mathrm{~g}, \text { lid } 1.7 \mathrm{~g} \text { ) }\end{array}$ & $18.2 \mathrm{~g}(+11.7 \mathrm{~g})$ & $0 \%$ & Not degraded \\
\hline I.3.3.D Paper & Plate $(1.7 \mathrm{~g})$, cup $(1.9 \mathrm{~g})$ & $0 \mathrm{~g}(-3.6 \mathrm{~g})$ & $100 \%$ & Soft to the touch \\
\hline I.3.4.D PLA/CPLA & $\begin{array}{c}\text { PLA (cup } 2.5 \mathrm{~g} \text { )/ } \\
\text { CPLA (knife } 2.3 \mathrm{~g}, \text { lid } 1.7 \mathrm{~g})\end{array}$ & $9.1 \mathrm{~g}(+2.6 \mathrm{~g})$ & $0 \%$ & Not degraded \\
\hline
\end{tabular}


Table 3. Results of the degradation of selected items in Station S3, Gehlsdorf (G).

\begin{tabular}{|c|c|c|c|c|}
\hline $\begin{array}{c}\text { Incubators and } \\
\text { Content }\end{array}$ & Initial Weights of Samples & Final Total Weight & $\begin{array}{c}\text { Degradation } \\
\text { Rate }(\%)\end{array}$ & $\begin{array}{l}\text { Final Status } \\
\text { of the Item }\end{array}$ \\
\hline G.1.1.U Sugar cane & Bleached $(1.6 \mathrm{~g}) /$ unbleached $(1.9 \mathrm{~g})$ & $0 \mathrm{~g}(-3.5 \mathrm{~g})$ & $100 \%$ & Totally degraded \\
\hline G.1.2.U PLA/CPLA & $\begin{array}{l}\text { PLA (cup } 1 \mathrm{~g} \text {, box } 1.8 \mathrm{~g} \text { )/CPLA } \\
\text { (lid } 1.5 \mathrm{~g} \text {, spoon } 3.1 \mathrm{~g} \text {, knife } 2.5 \mathrm{~g} \text { ) }\end{array}$ & $11.6 \mathrm{~g}(+1++6.7 \mathrm{~g})$ & $0 \%$ & Not degraded \\
\hline G.1.3.D Sugar cane & Bleached (1.6 g), unbleached (1.8 g) & $0 \mathrm{~g}(-3.4 \mathrm{~g})$ & $100 \%$ & Totally degraded \\
\hline G.1.4.D PLA/CPLA & $\begin{array}{l}\text { PLA (cup } 1 \mathrm{~g} \text {, box } 1.8 \mathrm{~g} \text { )/CPLA } \\
\text { (lid } 1.6 \mathrm{~g} \text {, spoon } 2.7 \mathrm{~g} \text {, knife } 1.9 \mathrm{~g} \text { ) }\end{array}$ & $10.6 \mathrm{~g}(+1.6 \mathrm{~g})$ & $0 \%$ & Not degraded \\
\hline G.2.1.U Palm leaf & Plate (4 g) & $0 \mathrm{~g}(-4 \mathrm{~g})$ & $100 \%$ & Totally degraded \\
\hline G.2.2.U Wood & Spoon $(2.3 \mathrm{~g})$, stick $(0.7 \mathrm{~g})$ & $6.7 \mathrm{~g}(+3.7 \mathrm{~g})$ & $0 \%$ & Soft to the touch \\
\hline G.2.3.D Palm leaf & Plate $(4.2 \mathrm{~g})$ & $1.3 \mathrm{~g}(-2.9 \mathrm{~g})$ & $69 \%$ & Small fibers \\
\hline G.2.4.D Wood & Spoon $(1.5 \mathrm{~g})$, stick (0.8 g) & $4.6 \mathrm{~g}(+2.3 \mathrm{~g})$ & $0 \%$ & Soft to the touch \\
\hline G.3.1.U Paper & Plate (1.6 g), cup (1.7 g) & $0 \mathrm{~g}(-3.3 \mathrm{~g})$ & $100 \%$ & Soft to the touch \\
\hline G.3.2.U Plastics & Cup $(0.8 \mathrm{~g})$, box $(1.6 \mathrm{~g})$ & $3.3 \mathrm{~g}(+0.9 \mathrm{~g})$ & $0 \%$ & Not degraded \\
\hline G.3.3.D Paper & Plate $(1.7 \mathrm{~g})$, cup $(1.7 \mathrm{~g})$ & $1.3 \mathrm{~g}(-2.1 \mathrm{~g})$ & $61.7 \%$ & Soft to the touch \\
\hline G.3.4.D Plastics & Cup (0.9 g), box (1.7 g) & $3.2 \mathrm{~g}(+0.6 \mathrm{~g})$ & $0 \%$ & Not degraded \\
\hline
\end{tabular}

At $\mathrm{S1}$, the results show that the DR of sugar cane and palm leaf placed in the upper and lower incubators was high. Paper was relatively resistant to the water conditions $(42.1 \%$ and $31.8 \%$ ), but its morphology changed considerably, and it tended to degrade. However, PS, PLA/CPLA and wood in both upper and lower incubators were not degraded (DR: $0 \%$ ). In addition, it was noted that barnacles were growing on its surface, which explain the gain in weight $(+0.2$ to +2.2$)$. In fact, as larvae, barnacles have a size between 0.35 and $1 \mathrm{~mm}$ [43], they can easily get inside the incubators which have a $2 \mathrm{~mm}$ mesh size. Barnacles were then able to fix themselves to materials.

The found results are also presented by examples of the final status of the items at S1 in Figure 6.

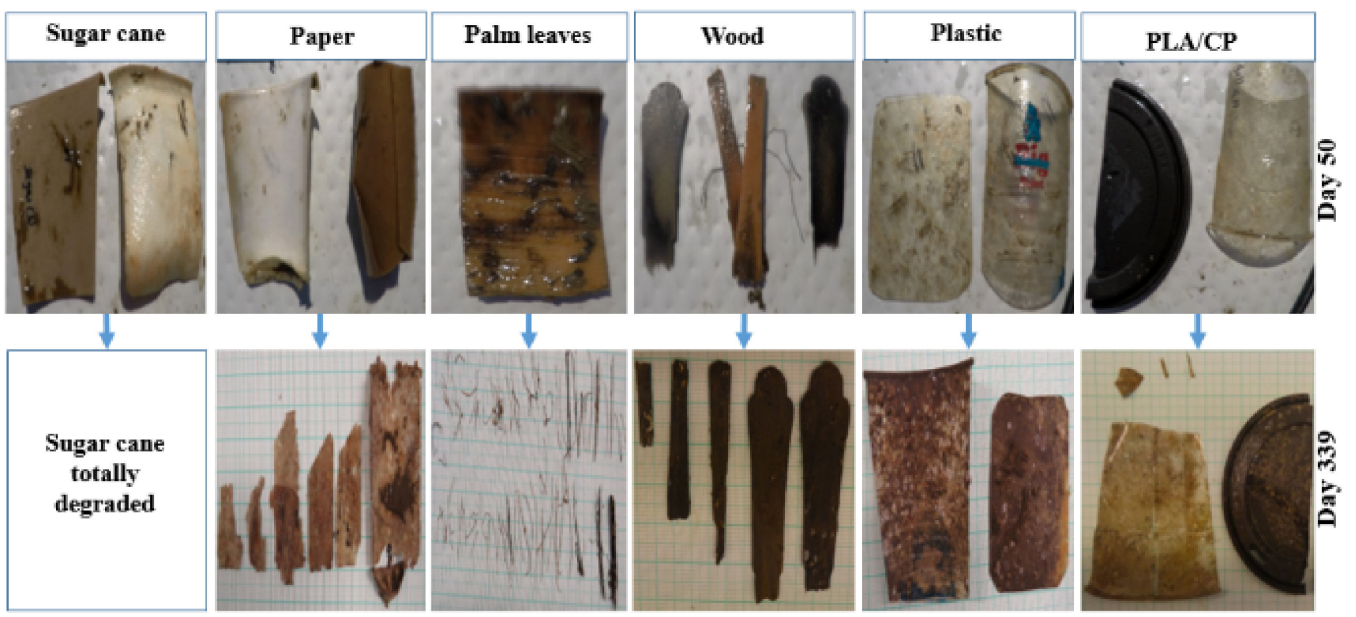

Figure 6. Examples of degraded items from the upper incubators at S1.

Results at S2 showed that the DR of paper, palm leaf and sugar canes items of the upper incubators was high (100\%) and were relatively important in most lower incubators. Palm leaf degraded to small fibers which explains the registered weight. However, PS, wood and PLA/CPLA were resistant to the water conditions and degradation did not take place during the experimentation period. In fact, the process of degradation seemed to start 
at that period of time. Figure 7 shows examples of items and differences noted between first time opening the incubators and the end of experiments.
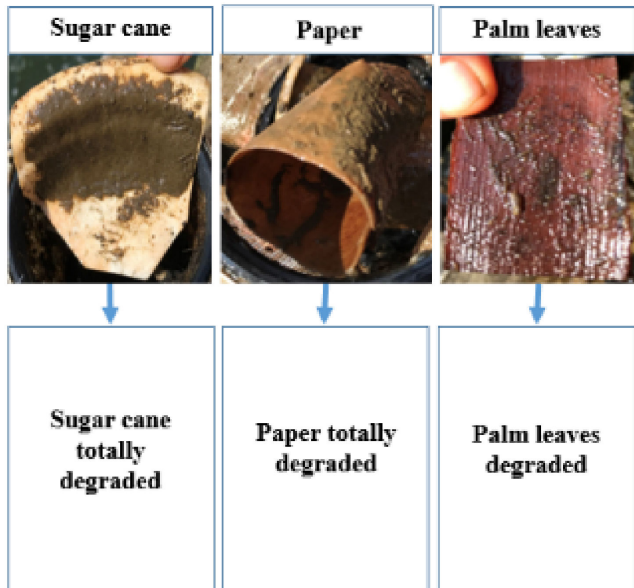
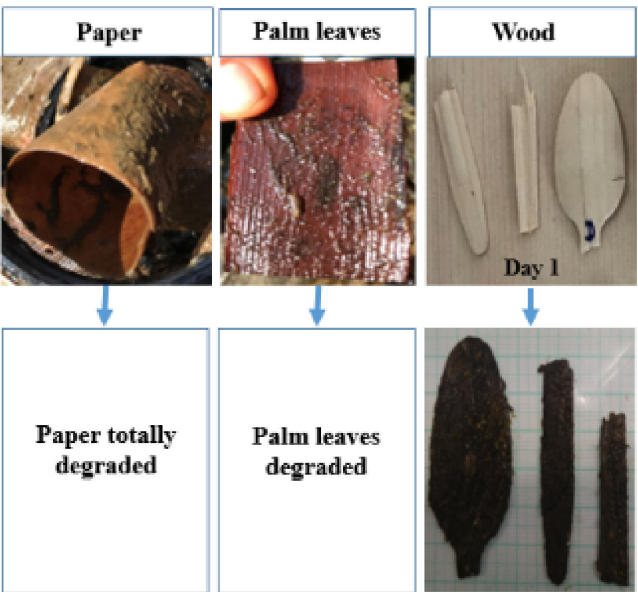
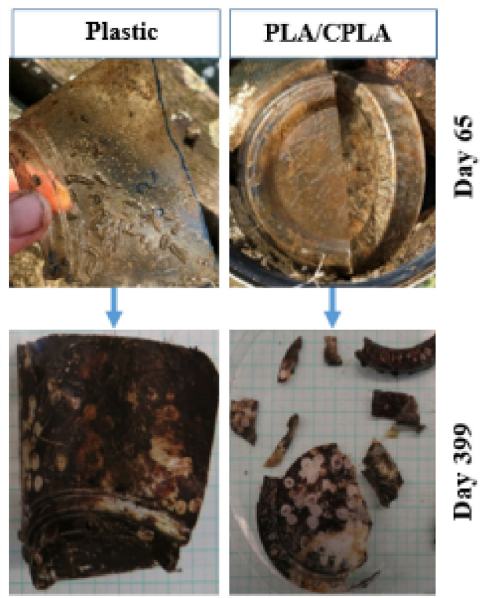

Figure 7. Examples of degraded items from the upper incubators at S2.

At S3, sugar cane, palm leaf and paper items in the upper incubators totally degraded (DR: 100\%). However, palm leaf items placed in the lower incubator degraded to a form of small fibers resulting in a DR of $65 \%$. In addition, paper items in the lower incubators lost weight and changed their morphology. However, they did not degrade totally. No change was registered regarding PLA/CPLA, wood and PS items in terms of DR. On the contrary, their color changed, showing also a growth of barnacles, algae and mussels on top. As for S1 and S2, examples of difference between the items is presented in Figure 8.

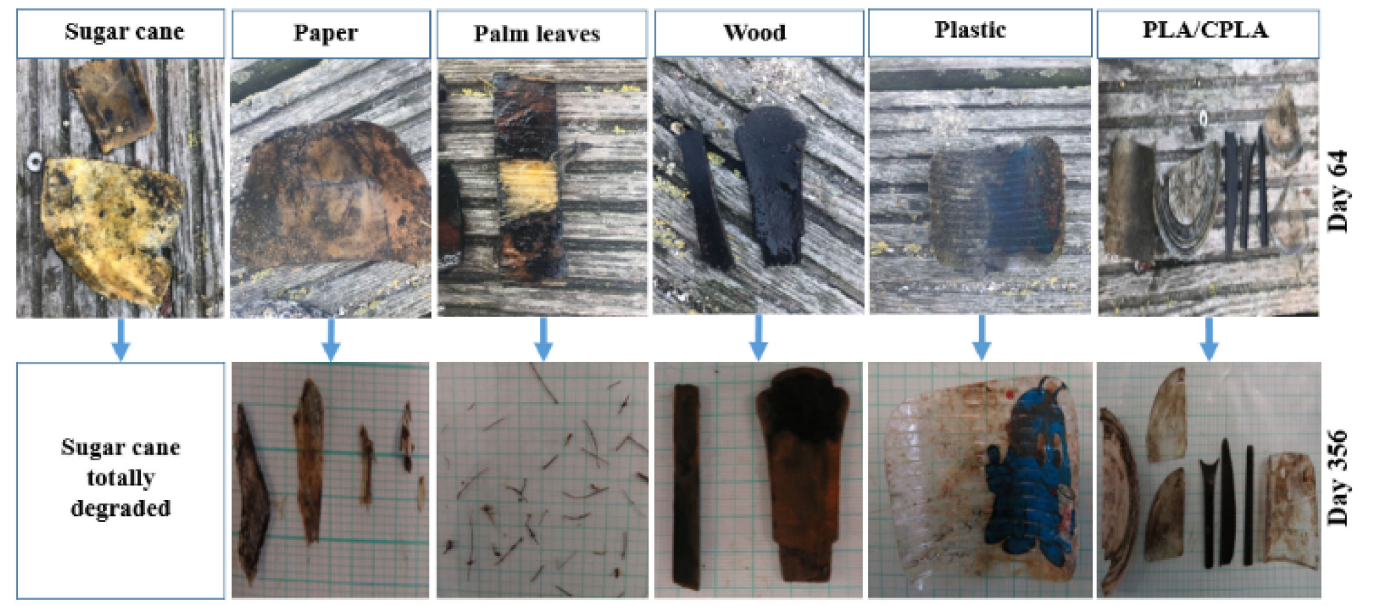

Figure 8. Examples of degraded items from the upper incubators at S3.

\subsection{Parameters and DR Monitoring}

In this research it was not possible to follow the degradation rate of items periodically through weighing. In fact, most items were very wet, fragile and soft to the touch. The weighing operation could have lost some parts of the material and distorted the results. However, and in order to assess the influence of the monitored parameters on the DR, an estimation of the degradation is noted, based on the photographs taken during the field visits. The results of the parameter monitoring and the DR of the materials used are presented in Figures 9-11: 


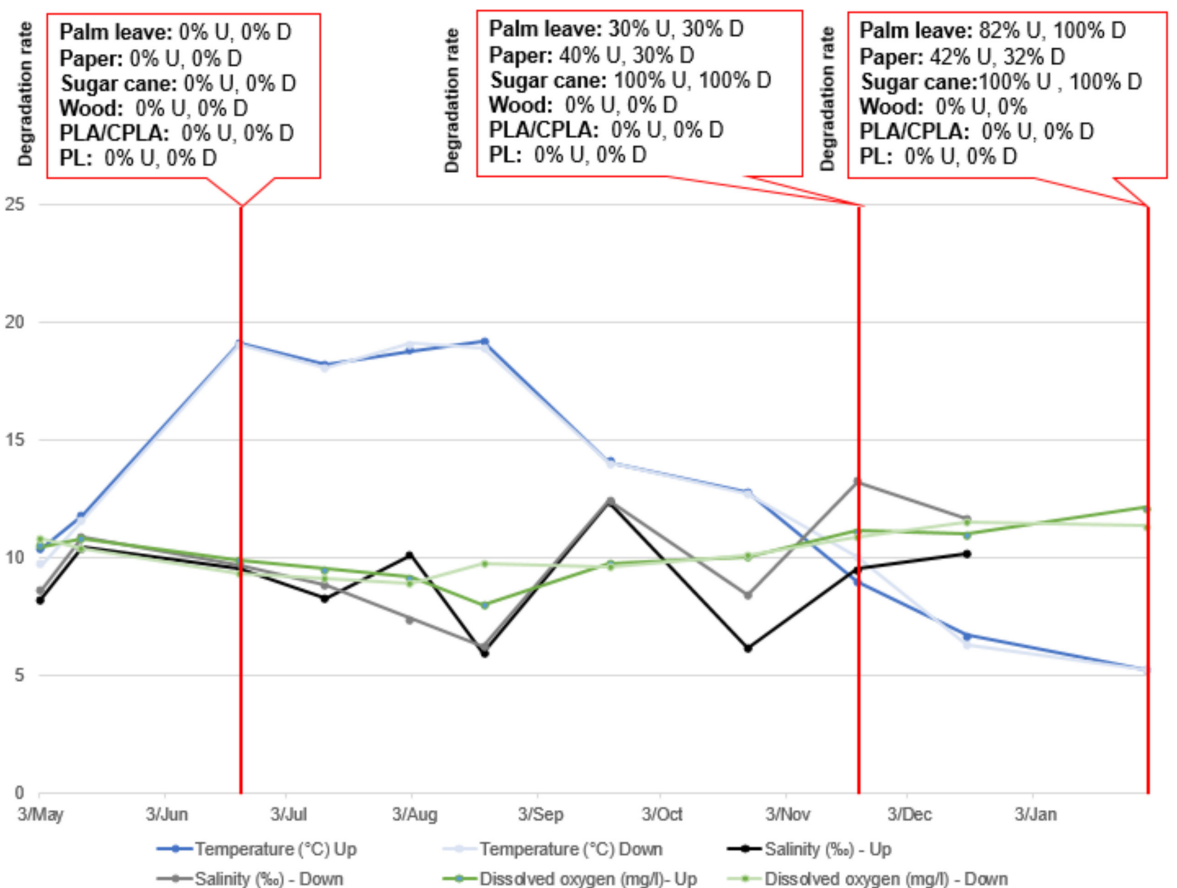

Figure 9. Parameter variation and DR in Upper and Lower incubators at S1.

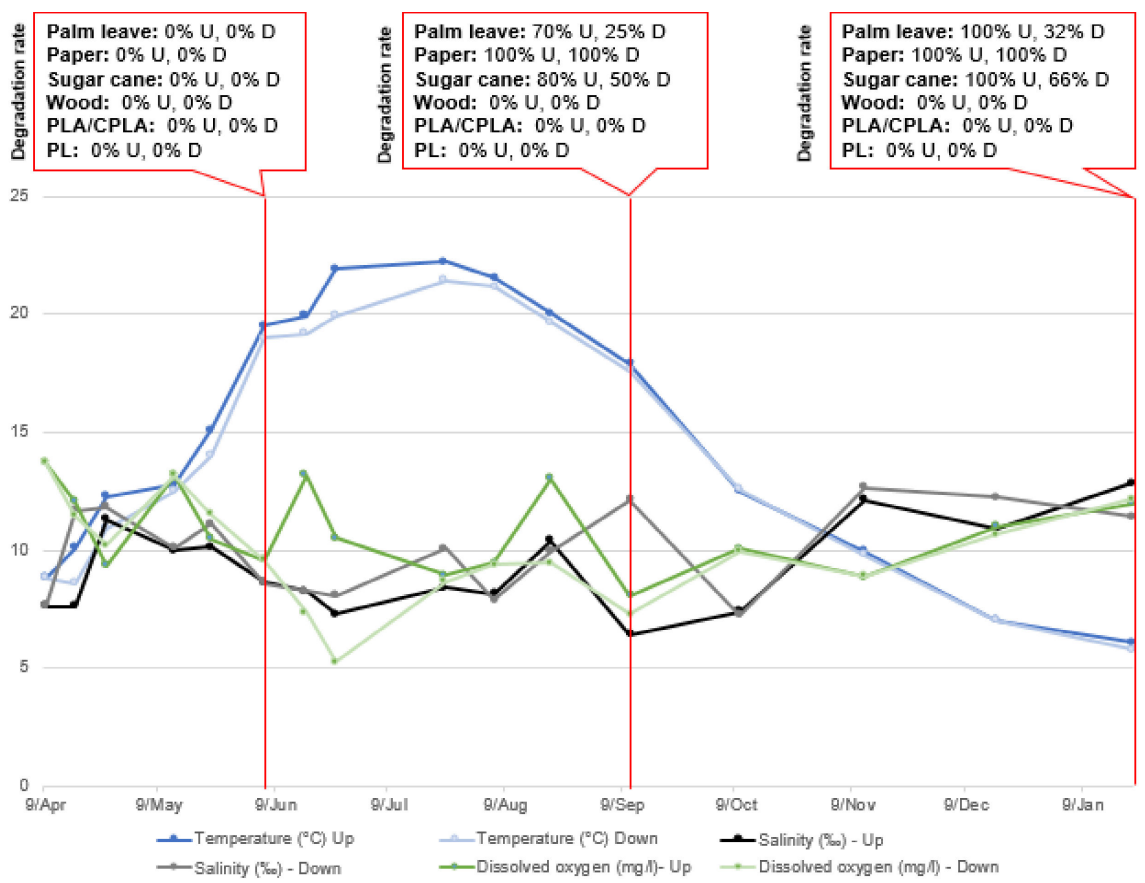

Figure 10. Parameter variation and DR in Upper and Lower incubators at S2.

The characteristic parameters of natural water have a certain fluctuation caused by seasonal changes. Among them, water temperature shows the most obvious fluctuation between $4.7^{\circ} \mathrm{C}$ and $24.4{ }^{\circ} \mathrm{C}$ (in the upper layer) and $5.2^{\circ} \mathrm{C}$ and $22.7^{\circ} \mathrm{C}$ (in the lower layer). The $\mathrm{pH}$ does not change significantly. The same is true in terms of salinity, with average values of $2.8 \%$ and $12.8 \%$ (in upper layer) and $6.7 \%$ and $13.2 \%$ (in the lower layer), respectively. The DO was not stable in either the upper or lower incubators. 


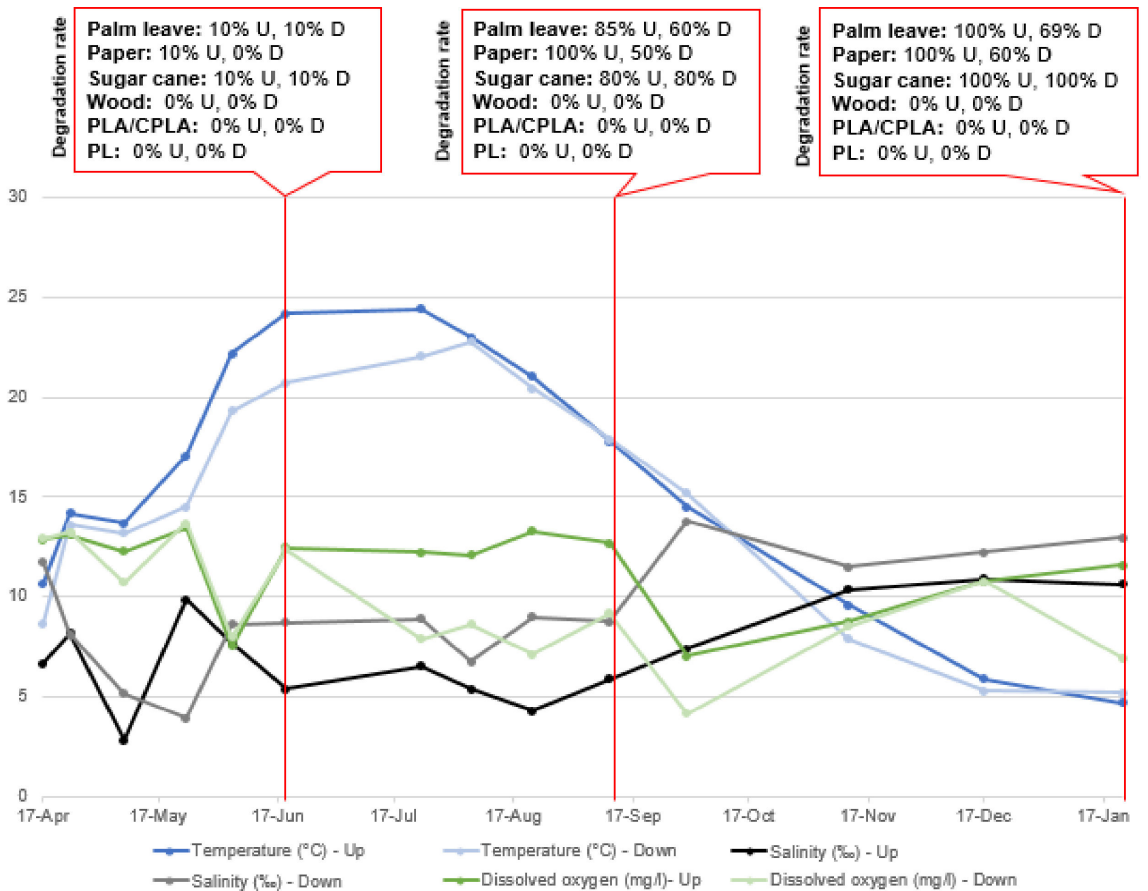

Figure 11. Parameter variation and DR in Upper and Lower incubators at S3.

\section{Discussion}

Degradation is assessed by measuring the decay of relevant physical properties, such as changes in molecular weight mass and molecular mass distribution, tensile properties, mass loss, morphological changes, etc. [44-46]. In this research, both mass loss and morphological changes were considered. It is important then to characterize the degradation rate of several bio-based items because these materials can be applied in several economic activities in coastal areas, where the possible end-of-life is actually the sea. Therefore, suitable test methodologies are required.

The current study has been carried out during one year of incubation of the items in the Warnow estuary. The study confirms the results highlighted by Law. K.L. et al., that prolonged exposure to environmental factors such as heat, light or microbial action causes polymers to be degraded into smaller pieces [47].

After completion of the experiment, the main findings indicate that palm leaf, sugar cane bagasse and paper/cellulose almost degraded in most incubator locations, but not with the same rapidity of degradation. This depended on the station location and the position in the water column (in the upper or lower level). In fact, according to Jambeck et al., the exposure to UV radiation and oxygen causes photodegradation. These processes occur to a depth of 50-100 $\mu \mathrm{m}$ and result in molecular weight reduction [48]. In addition, the morphology of some partially degraded materials changed, either slightly or considerably.

\subsection{Final Morphology of Tableware Items}

The morphology represents an important criterion for predicting the possible future of the tested tableware items. This changes differently, depending on the material and its characteristics. For example, most of the partial degraded palm leaf samples were transformed into fibers or into pieces which were very soft to the touch. Likewise, the nondegraded parts of sugar cane were very thin, and decomposed into pieces, with a brown color. In addition, incubators containing wood items were partly filled with barnacles and mussels using the samples as habitats. The morphology of wood items slightly changed, their color became darker and a bit softer to the touch. These changes indicated that the degradation process could have been started. 
At some stations, paper samples were covered by a thin layer of biofilm and some barnacles. The material was very soft and easily crushed, resulting in a complete loss of mechanical properties.

Finally, no changes were noted in terms of the shape of PLA with some change of color, which was the case for [49]. Same for the common plastic PS and CPLA. An important growth of mussels and barnacles on top of the samples and inside the incubators was noted.

\subsection{Influence of Temperature on $D R$}

The degradation of the placed items in all stations started in June, when the temperature increased considerably. Before June, the DR was, in most cases, $0 \%$ for all tested materials, and reached higher percentages by the end of the summer period. The experimental findings showed the important role of temperature with regard to accelerating the degradation of palm leaf, sugar cane and paper, particularly in the upper incubators, where the temperature was relatively higher than in the bottom due to its greater exposure to the sun. However, the results indicate that the temperature parameter had no effects on the degradation of PLA, CPLA and PS tableware.

For instance, the results confirm the finding of Huang. D et al. [49] that for example PLA, which exhibits excellent degradation performance in controlled industrial composting, shows no degradation in the ocean. The main reason behind is that the temperature in seawater is considered relatively low and the specific microbial species and number are less, resulting in obvious inhibition of the degradation process. This is also the case of CPLA and plastics items tested in the context of this research.

The results of the research carried out by Bagheri. A.R et al., on different materials including PLA, aimed to test their biodegradability in sea water and freshwater in a thermostatic chamber at $25^{\circ} \mathrm{C}$ and under fluorescent light (16 h light and $8 \mathrm{~h}$ dark) for one year, showed that PLA did not show any significant degradability under the testing conditions [50].

The influence of weathering on different materials represents a complex issue. The degradation of the material depends on some different parameters, such as the temperature, mechanical factors, sunlight and the sample depth, which makes the analyses of the influence a complex issue [51,52].

This research of the degradation of tested items in the water column in the Warnow estuary indicates the potential that certain environmental parameters have, such as seawater temperature, sample depth and sunlight, to accelerate or to slow the degradation. The potential of the rest of parameters is still not known and needs a deeper analysis.

\section{Conclusions and Recommendations}

The Warnow River estuary is an area of Rostock city where several important events and activities take place during the year, which leads to a generation of high emissions of single-use tableware. This type of pollution differs from one area to another in the Warnow estuary. Therefore, three different stations were selected based on different placements, parameters and type of activities.

In this regard, a number of lessons learned could be transferred to future studies, such as ensuring the accessibility to the incubators, as well as the safety of the incubators while selecting the areas of experimentation.

The field work requires a regular check-up of the installed equipment in order to ensure the continuity of the experiments without disturbing the degradation process.

The main findings of this research indicate that tableware items composed of palm leaf, sugar cane and paper are less resistant to the seawater physicochemical parameters than wood, PLA, CPLA and plastic (PS) items, which showed a certain resistance during the experimentation period. Furthermore, items placed in the upper incubators degraded relatively faster in most cases than those of the same material and placed in the lower incubators. 
Furthermore, the results showed that the temperature and exposure to sunlight could be the main factors that accelerate the degradation of the materials. The degradation could also be related to the presence of water current and a greater amount of pelagic organisms. However, in this study the potential of these parameters on the DR has not been proved. Therefore, further studies will be needed to complete and fully check the test methodology used, in terms of the determination of both physical and biological degradation.

Based on the findings, it is recommended to consider sugar cane, palm leaf and paper items since they mainly degraded in the water condition of the Warnow estuary. However, it is desirable to continue testing the rest of items for a longer period to ensure an accurate average in terms of DR based on weather condition changes. It is also recommended that more tableware items be tested, particularly those recently put on the market. This study has some other limitations that need to be addressed. For example, the fact that the selected items have not been tested in other areas or countries with different weather conditions, in particular a higher temperature.

Experimentally speaking, its recommended that there is a need to test the degradability of materials through placing an incubator at the bottom of the water column. In fact, according to Schernewski G. et al. [13], the growth of bacteria and algae on the littered item in the water column increases in density and causes its deposition at the bottom.

In addition, mechanical destruction experimentations within the laboratory and under controlled conditions could be relevant to test the effect of water movements and currents on the DR of the items.

Moreover, the importance of specific factors and conditions such as temperature, UV light, $\mathrm{pH}$ and salinity in accelerating the degradation of items in the water column are still largely unknown. Therefore, it is highly recommended to develop further research to test the relation of the degradation parameters, to ensure a better understanding of the degradation process, and consequently, to support innovation in terms of the optimization of biodegradable item production.

Author Contributions: Conceptualization, A.B.C., G.S. and H.S.; methodology, A.B.C., G.S. and H.S.; validation, A.B.C., G.S. and H.S.; formal analysis, A.B.C. and E.R.; investigation, A.B.C. and E.R.; data curation, A.B.C., G.S. and H.S.; writing original draft preparation, A.B.C.; writing review and editing, A.B.C., E.R., G.S. and H.S.; supervision, G.S. and H.S. All authors have read and agreed to the published version of the manuscript.

Funding: This research was partly funded by the BMBF project MicroCatch-Balt (03F0788A).

Institutional Review Board Statement: Not applicable.

Informed Consent Statement: Informed consent was obtained from all subjects involved in the study.

Data Availability Statement: Not applicable.

Acknowledgments: We would like to thank all contributors who supported the field work and the data collection, particularly Sophia Drs. A special thanks goes to Brittan Scales from the Leibniz Institute for Baltic Sea Research Warnemünde (IOW) for providing the body of the incubators used for the experiments. Special thanks are addressed to M.Sc. Tabea Lange from the Marine Science Center at Hohe Düne, at IGA Park, Petra Wild and Ronald Förster and his team from the Ruder Club at Gehlsdorf for ensuring access to the experimental locations. A particular recognition goes to Matthias Welk and his team from the Municipality of Rostock for providing all the required tableware samples for the in situ experiments.

Conflicts of Interest: The authors declare no conflict of interest.

\section{References}

1. Galgani, F.; Hanke, G.; Maes, T. Global distribution, composition and abundance of marine litter. In Marine Anthropogenic Litter; Bergmann, M., Gutow, L., Klages, M., Eds.; Springer: Berlin, Germany, 2015; pp. 29-56.

2. Ryan, P.G. A brief history of marine litter research. In Marine Anthropogenic Litter; Bergmann, M., Gutow, L., Klages, M., Eds.; Springer: Berlin, Germany, 2015; pp. 1-25. 
3. Thompson, R.C. Microplastics in the marine environment: Sources, consequences and solutions. In Marine Anthropogenic Litter; Bergmann, M., Gutow, L., Klages, M., Eds.; Springer: Berlin, Germany, 2015; pp. 185-200.

4. Barnes, D.K.A.; Galgani, F.; Thompson, R.C.; Barlaz, M. Accumulation and fragmentation of plastic debris in global environments. Philos. Trans. R. Soc. B Biol. Sci. 2009, 364, 1985-1998. [CrossRef]

5. Kühn, S.; Bravo Rebolledo, E.L.; van Franeker, J.A. Deleterious effects of litter on marine life. In Marine Anthropogenic Litter; Bergmann, M., Gutow, L., Klages, M., Eds.; Springer: Berlin, Germany, 2015; pp. 75-116.

6. Veiga, J.M.; Fleet, D.; Kinsey, S.; Nilsson, P.; Vlachogianni, T.; Werner, S.; Galgani, F.; Thompson, R.C.; Dagevos, J.; Gago, J.; et al. Identifying Sources of Marine Litter. In MSFD GES TG Marine Litter Thematic Report; JRC Technical Report; European Union: Luxembourg, 2016. [CrossRef]

7. Morritt, D.; Stefanoudis, P.V.; Pearce, D.; Crimmen, O.A.; Clark, P.F. Plastic in the Thames: A river runs through it. Mar. Pollut. Bull. 2014, 78, 196-200. [CrossRef]

8. Free, C.M.; Jensen, O.P.; Mason, S.A.; Eriksen, M.; Williamson, N.J.; Boldgiv, B. High-levels of microplastic pollution in a large, remote, mountain lake. Mar. Pollut. Bull. 2014, 85, 156-163. [CrossRef] [PubMed]

9. Hoellein, T.; Rogas, M.; Pink, K.; Gasior, J.; Kelly, J. Anthropogenic litter in urban freshwater ecosystems: Distribution and microbial interactions. PLoS ONE 2014, 9, e98485. [CrossRef] [PubMed]

10. Teuten, E.; Rowland, S.; Galloway, T.; Thompson, R. Potential for plastics to transport hydrophobic contaminants J. Environ. Sci. Technol. 2007, 41, 7759-7764. [CrossRef] [PubMed]

11. Mato, Y.; Isobe, T.; Takada, H.; Kanehiro, H.; Ohtake, C. Plastic resin pellets as a transport medium for toxic chemicals in the marine environment. J. Environ. Sci. Technol. 2001, 35, 318-324. [CrossRef]

12. HELCOM. State of the Baltic Sea/Marine Litter 2018. Available online: http:/ / stateofthebalticsea.helcom.fi/pressures-and-theirstatus/marine-litter/ (accessed on 15 August 2021).

13. Schernewski, G.; Radtke, H.; Robbe, E.; Haseler, M.; Hauk, R.; Meyer, L.; Piehl, S.; Riedel, J.; Labrenz, M. Emission, Transport, and Deposition of visible Plastics in an Estuary and the Baltic Sea-A Monitoring and Modeling Approach. J. Environ. Manag. 2021, 68, 860-881. [CrossRef]

14. Official Journal of the European Union. DIRECTIVE (EU) 2019/904 of the European Parliament and of the Council on the Reduction of the Impact of Certain Plastic Products on the Environment, L 155/2. 2019. Available online: https: / / eur-lex.europa. eu/legal-content/EN/TXT/PDF/?uri=CELEX:32019L0904 (accessed on 14 January 2022).

15. Ross, P.C. Plastic in the Environment 2019. Available online: https://www.researchgate.net/publication/3353338250_Plastics_in_ the_Environment (accessed on 22 August 2021).

16. Rochman, C.; Browne, M.; Halpern, B.; Hentschel, B.; Hoh, E. Classify plastic waste as hazardous. Nature 2013, 494, 169-171. [CrossRef]

17. Koelmans, A.A.; Besseling, E.; Foekema, E.M. Leaching of plastic additives to marine organisms. Environ. Pollut. 2014, 187, 49-54. [CrossRef]

18. Teuten, E.L.; Saquing, J.M.; Knappe, D.R.; Barlaz, M.A.; Jonsson, S.; Björn, A.; Rowland, S.J.; Thompson, R.C.; Galloway, T.S.; Yamashita, R.; et al. Transport and release of chemicals from plastics to the environment and the wildlife. Phil. Trans. R. Soc. B 2009, 364, 2027-2045. [CrossRef]

19. Bakir, A.; Rowland, S.J.; Thompson, R.C. Enhanced desorption of persistent organic pollutants from microplastics under simulated physiological conditions. Environ. Pollut. 2014, 185, 16-23. [CrossRef]

20. European Bioplastics. FACT SHEET: Bioplastics-Industry Standards and Labels. 2019. Available online: https://www.europeanbioplastics.org/new-market-data-2019-bioplastics-industry-shows-dynamic-growth/ (accessed on 30 January 2021).

21. Kržan, A. Biodegradable Polymers and Plastics 2012. Available online: https:/ / docplayer.net/21617366-Biodegradable-polymersand-plastics-andrej-krzan.html (accessed on 22 August 2021).

22. ADEME. Biodegradable Plastics. European Standard EN NF 13432 Relating to the Requirements Relating to Packaging Recoverable by Composting and Biodegradation. ADEME Technical Sheets. 2012. Available online: https://librairie.ademe.fr/dechetseconomie-circulaire/3064-plastiques-biodegradables.html (accessed on 27 July 2021).

23. Tadahisa, I. Biodegradable and Bio-Based Polymers: Future Prospects of Eco-Friendly Plastics. Angezw. Chem. Int. Ed. 2015, 54, 3210-3215. [CrossRef]

24. Mudgal, S.; Muehmel, K.; Hoa, E.; Grémont, M.; Labouze, E. Options to Improve the Biodegradability Requirements in the Packaging Directive; Final Report; Prepared for DG Environment-European Commission; BIO Intelligence Service: Paris, France, 2012.

25. Tokiwa, Y.; Calabia, B.P. Biodegradability and Biodegradation of Polyesters. J. Polym. Environ. 2007, 15, 259-267. [CrossRef]

26. Song, J.H.; Murphy, R.J.; Narayan, R.; Davies, G.B.H. Biodegradable and compostable alternatives to conventional plastics. Philos. Trans. R. Soc. B Biol. Sci. 2009, 364, 2127-2139. [CrossRef]

27. UNEP. Biodegradable Plastics and Marine Litter. Misconceptions, Concerns and Impacts on Marine Environments. United Nations Environment Programme (UNEP), Nairobi. 2015. Available online: https:/ / wedocs.unep.org/handle/20.500.11822/746 8 ? show $=$ full (accessed on 22 August 2021).

28. Lange, X. Numerical Simulations of Estuarine Circulation in a Non-Tidal Estuary. Master's Thesis, Dissertation, Leibniz Institute for Baltic Sea Research Warnemünde Partner Institute, Mathematical-Scientific Faculty, University of Rostock, Rostock, Germany, 2015. 
29. Oberbeckmann, S.; Kreikemeyer, B.; Labrenz, M. Environmental Factors Support the Formation of Specific Bacterial Assemblages on Microplastics. Front. Microbiol. 2018, 8, 2709. [CrossRef]

30. Drumright, R.E.; Gruber, P.R.; Henton, D.E. Polylactic acid technology. J. Adv. Mater. 2009, 12, 841-1846. [CrossRef]

31. Fukushima, K.; Sogo, K.; Miura, S.; Kimura, Y. Production of D-lactic acid by bacterial fermentation of rice starch. Macromol. Biosci. 2004, 4, 1021-1027. [CrossRef]

32. Timbuktu, W.; Sriroth, K.; Tokiwa, Y. Lactic acid production from sugar-cane juice by a newly isolated Lactobacillus sp. Biotechnol. Lett. 2006, 28, 811-814.

33. Alaerts, L.; Augustinus, M.; Van Acker, K. Impact of Bio-Based Plastics on Current Recycling of Plastics. Sustainability 2018, 10, 1487. [CrossRef]

34. Ohkita, T.; Lee, S.H. Thermal degradation and biodegradability of poly (lactic acid)/corn starch biocomposites. J. Appl. Polym. Sci. 2006, 100, 3009-3017. [CrossRef]

35. Popa, M.E.; Mitelut, A.; Niculita, P.; Geicu, M.; Ghidurus, M.; Turtoi, M. Biodegradable Materials for Food Packaging Applications. J. Environ. Prot. Ecol. 2011, 12, 1825-1834.

36. Pradeep, P.; Edwin Raja Dhas, J. Characterization of chemical and physical properties of palm fibers. MSEJ 2015, 2, 01-06. [CrossRef]

37. Wahid, M.K.; Ahmad, M.N.; Osman, M.H.; Maidin, N.A.; Rahman, M.H.A.; Firdaus, H.M.S.; Kasno, M.A. Development of Biodegradable Plastics for Packaging using wastes from oil palm and sugar cane. IJRTE 2019, 8.

38. Sonntag, R.E.; Borgnakke, C.; Van Wylen, G.J. Fundamentals of Thermodynamics, 5th ed.; Wiley \& Sons Inc.: Hoboken, NJ, USA, 1998; p. 649.

39. Beer, F.P.; Johnston, E.R. Mechanics of Materials. In J Scientific Research, 2nd ed.; McGraw-Hill: New York, NY, USA, 1992.

40. Dobrowolska, E.; Wroniszewska, P.; Jankowska, A. Density Distribution in Wood of European Birch (Betula pendula Roth.). Forests 2020, 11, 445. [CrossRef]

41. National Institute of Standards and Technology. 2020. Available online: https:/ /www.nist.gov / (accessed on 17 July 2021 ).

42. Tokiwa, Y.; Ugwu, U.S.; Calabia, B.P. Biodegradability of Plastics. IJMS 2009, 10, 3722-3742. [CrossRef] [PubMed]

43. Carlton, J.T. The Light and Smith Manual, Intertidal Invertebrates from Central California to Oregon, 4th ed.; University of California Press: Berkeley, CA, USA, 2007. [CrossRef]

44. Rutkowska, M.; Heimowska, A.; Krasowska, K.; Janik, H. Biodegradability of polyethylene starch blends in sea water. Pol. J. Environ. Stud. 2002, 11, 267-274.

45. Rutkowska, M.; Krasowska, K.; Heimowska, A.; Steinka, L.; Janik, H.; Haponiuk, J.; Karlsson, S. Biodegradation of modified poly( $\varepsilon$-caprolactone) in different environments. Pol. J. Environ. Stud. 2002, 11, 413-420.

46. Rutkowska, M.; Jastrzebska, M.; Janik, H. Biodegradation of polycaprolactone in sea water. React. Funct. Polym. 1998, 38, 27-30. [CrossRef]

47. Law, K.L.; Morét-Ferguson, S.E.; Goodwin, D.S.; Zettler, E.R.; DeForce, E.; Kukulka, T.; Proskurowski, G. Distribution of Surface Plastic Debris in the Eastern Pacific Ocean from an 11-Year Data Set. J. Environ. Sci. Technol. 2014, 48, 4732-4738. [CrossRef] [PubMed]

48. Jambeck, J.R.; Geyer, R.; Wilcox, C.; Siegler, T.R.; Perryman, M.; Andrady, A.; Narayan, R.; Law, K.L. Plastic waste inputs from land into the ocean. Science 2015, 347, 768-771. [CrossRef]

49. Huang, D.; Hu, Z.D.; Liu, T.Y.; Lu, B.; Zhen, Z.C.; Wang, G.X.; Ji, J.H. Seawater degradation of PLA accelerated by water-soluble PVA. e-Polymers 2020, 20, 759-772. [CrossRef]

50. Bagheri, A.R.; Laforsch, C.; Greiner, A.; Agarwal, S. Fate of so-called biodegradable polymers and freshwater. Glob. Chall. 2017, 1, 1700048. [CrossRef]

51. Ter Halle, A.; Ladirat, L.; Martignac, M.; Mingotaud, A.F.; Boyron, O.; Perez, E. To what extent are microplastics from the open ocean weathered? J. Environ. Pollut. 2017, 227, 167-174. [CrossRef]

52. Chubarenko, I.P.; Esiukova, E.E.; Bagaev, A.V.; Bagaeva, M.A.; Grave, A.N. Three-dimensional distribution of anthropogenic microparticles in the body of sandy beaches. Sci. Total Environ. 2018, 628, 1340-1351. [CrossRef] 